\title{
Analiza normatywna dochodów budżetowych uzyskiwanych z cel w polskim porządku prawnym
}

\section{Normative analysis of budgetary incomes from customs in the Polish legal system}

Streszczenie. Budżet państwa stanowi główną instytucję prawa budżetowego. Jest przedmiotem regulacji wielu przepisów prawnych, w tym przepisów konstytucyjnych i ustawy o finansach publicznych, z których wynikają jego rozmaite właściwości. Jest on uchwalany przez Sejm jako najwyższy plan finansowy polityki państwa oraz narzędzie polityki społeczno-gospodarczej, uwzględniający planowane dochody i wydatki państwa na następny rok budżetowy. Z punktu widzenia dochodów w budżecie państwa uwzględnia się m.in.: wpływy z podatków pośrednich i bezpośrednich, dochody niepodatkowe. Cła, jako świadczenia o charakterze niepodatkowym ${ }^{1}$ pobierane przez polską administrację celną

1 W doktrynie prawa finansowego wskazuje się, że cła posiadają te same cechy stałe co podatek lub nawet wprost uznaje się je za podatki, por. W. Modzelewski, J. Pyssa, Zarys prawa celnego, [w:] H. Litwińczuk (red.), Prawo finansowe. Tom II, Prawo podatkowe, Warszawa 2012, s. 263. 
w handlu międzynarodowym, należą do szczególnych rodzajów dochodów budżetowych. Wykorzystując poszczególne elementy konstrukcyjne ceł, np. stawki, ulgi lub zwolnienia, ustawodawca może wpływać na wysokość uzyskiwanych dochodów. Poziom ten zależy także od wielkości importu, kursu walutowego, skali wykorzystania środków taryfowych i pozataryfowych polityki celnej.

Słowa kluczowe: cło; prawo celne; danina publiczna; budżet państwa; finanse publiczne.

Abstract. The state budget constitutes a main institution of a budget law. It is subject to the regulation of many legal provisions, including constitutional provisions and provisions of the Act on Public Finances, which results in various properties thereof. The state budget is established by the Sejm as the most important financial plan for the state policy and an instrument of social policy, taking into consideration planned incomes and expenses of the state for the following financial year. From the point of view of incomes, the state budget includes, among others: incomes from indirect and direct taxes and non-tax incomes. Customs, as benefits of a non-tax character, which are charged by the Polish customs administration in the international trade, belong to particular types of the budget incomes. By using particular construction elements of customs, e.g. rates, reliefs or exemptions, the legislator can influence the amount of incomes it obtains. This level also depends on the amount of an import, an exchange rate as well as the scale of using tariff and non-tariff measures of customs policy.

Keywords: customs; customs law; public levy; state budget; public finances.

\section{Wprowadzenie}

Cło jest jedną z danin publicznych, która stanowi dochód nie tylko polskiego budżetu, ale również budżetu związku publicznoprawnego, jakim jest Unia Europejska. Już w starożytności cło należało do istotnych instrumentów gromadzenia dochodów publicznych i po dzień dzisiejszy stanowi historycznie najstarszą formę gromadzenia przez instytucję (władzę) publiczną środków pieniężnych. Z upływem czasu pojawiły się inne rodzaje ceł, które mogą być pobierane razem z cłem „fiskalnym”. Do takich ceł należy zaliczyć m.in. cła antydumpingowe, cła antysubsydyjne oraz cła wyrównawcze. 
Dochody uzyskiwane z ceł przez Unię Europejską i Polskę służą realizacji zasadniczych celów zapisanych w podstawowych unijnych i krajowych aktach prawnych oraz zaspokajaniu - przynajmniej w niezbędnym zakresie - bieżących potrzeb publicznych, zasilając w ten sposób ich budżet.

Celem niniejszego opracowania jest przedstawienie analizy normatywnej dochodów budżetu państwa uzyskiwanych z ceł w polskim systemie prawnym. Zajęcie się tym zagadnieniem wynika również z faktu, że dochody budżetowe uzyskiwane $\mathrm{z}$ ceł $\mathrm{w}$ polskim porządku prawnym i wynikające $\mathrm{z}$ niego konsekwencje prawne są bardzo rzadko poddawane analizie przez przedstawicieli nauk prawnych. Tymczasem problematyka ta, ze względu na jej szczególnie doniosłe znaczenie dla interesów Unii Europejskiej, a także bezpośredni wpływ na sytuację obywateli, z całą pewnością zasługuje na wszechstronną analizę prawniczą.

Niewątpliwie jedną z podstawowych konsekwencji powstania Unii Europejskiej było stworzenie w jej ramach jednolitego rynku wewnętrznego. Na mocy Traktatu o funkcjonowaniu Unii Europejskiej ${ }^{2}$ podstawę regulacji w zakresie wymiany towarowej z zagranicą stanowi unia celna. Utworzenie unii celnej w odniesieniu do krajów członkowskich Unii Europejskiej oznacza wprowadzenie wspólnej zewnętrznej taryfy celnej dla towarów pochodzących z krajów trzecich; utworzenie wspólnego rynku wewnętrznego, połączonego ze zniesieniem różnych dokumentów i formalności celnych na przejściach granicznych państw członkowskich; zniesienie ceł przywozowych i wywozowych oraz opłat o skutku równoważnym pomiędzy państwami członkowskimi ${ }^{3}$. Nie ulega zatem wątpliwości, że Unia Europejska posiada wyłączną kompetencję w zakresie unii celnej, w tym m.in. kompetencje do wprowadzenia w wymianie międzynarodowej Wspólnej Taryfy Celnej oraz stanowienia na jej podstawie ceł.

2 Art. 30 TFUE traktatu o funkcjonowaniu Unii Europejskiej (wersja skonsolidowana Dz.Urz. UE C 326 z 26 października 2012 r., s. 47, dalej: TfUE).

3 Por. C. Kosikowski, Problem suwerenności finansowej państwa członkowskiego Unii Europejskiej, [w:] L. Etel, M. Tyniewicki (red.), Finanse publiczne i prawo finansowe - realia i perspektywy zmian. Księga Jubileuszowa dedykowana Profesorowi Eugeniuszowi Ruśkowskiemu, Białystok 2012, s. 99-100. 


\section{Istota i klasyfikacja środków publicznych}

Niniejsze rozważania należy rozpocząć od wyjaśnienia terminu „budżet państwa” oraz środki publiczne. W znaczeniu etymologicznym termin „budżet państwa” wywodzi się z języka łacińskiego - słowo bulga oznaczało skórzany mieszek przeznaczony do zbierania dochodów ${ }^{4}$. Pomimo, że pojęcie „budżetu państwa” ma podstawowe znaczenie dla polskiego prawa finansowego, brak wyrażonej wprost jego definicji w Konstytucji ${ }^{5}$ i w ustawie z dnia 27 sierpnia 2009 r. o finansach publicznych ${ }^{6}$. Obowiązująca ustawa o finansach publicznych nie definiuje wprost pojęcia „budżetu państwa” - tak jak to miało miejsce w uchylonej ustawie o finansach publicznych z 2005 r. $^{7}$ - akceptując natomiast rolę ustawy budżetowej, której podstawowym celem jest ustanowienie budżetu państwa. Zgodnie z przepisem art. 95 ust. 1 i 2 u.f.p. z 2005 r. budżet państwa był rocznym planem dochodów i wydatków oraz przychodów i rozchodów organów władzy publicznej, w tym organów administracji rządowej, organów kontroli i ochrony prawa, sądów i trybunałów, uchwalanym w formie ustawy (budżetowej) na okres roku kalendarzowego.

Podejmując przedmiotową analizę dochodów budżetowych uzyskiwanych $\mathrm{z}$ ceł $\mathrm{w}$ polskim porządku prawnym, należy przede wszystkim zauważyć, że Trybunał Konstytucyjny zwrócił uwagę na szczególne cechy ustawy budżetowej, które wyróżniają ją spośród innych ustaw. I tak np. w postanowieniu z dnia 20 czerwca 2001 r. podkreślił on jej odrębność w stosunku do innych ustaw. Jej treścią są normy planowe, skonkretyzowane czasowo i kwotowo, nie zaś normy prawne o charakterze generalnym i abstrakcyjnym ${ }^{8}$. Oznacza to, że ustawa budżetowa nie może

4 J. Sondel, Słownik łacińsko-polski dla prawników i historyków, Kraków 2009, s. 115. Słowo to przyjęło się następnie w wielu językach (ang. budget, starofrancuskim bougette, fr. le budget).

$5 \quad$ Konstytucja Rzeczypospolitej Polskiej z dnia 2 kwietnia 1997 r. (Dz.U. Nr 78, poz. 483 ze zm., dalej: Konstytucja).

6 Ustawa z dnia 27 sierpnia 2009 r. o finansach publicznych (Dz.U. z 2016 r., poz. 1870 ze zm., dalej: u.f.p.).

7 Ustawa z dnia 30 czerwca 2005 r. o finansach publicznych (Dz.U. Nr 249, poz. 2104 ze zm., dalej: u.f.p. z 2005 r.).

8 Postanowienie TK z dnia 20 czerwca 2001 r., sygn. K 35/00, LEX nr 49156. 
zmieniać innych ustaw. Ponadto podkreślić należy, że Konstytucja RP w art. 219 ust. 1 wprowadza zasadę, zgodnie z którą Sejm uchwala budżet państwa na rok budżetowy w formie ustawy budżetowej. Tak więc gospodarka finansowa państwa oparta została na uchwalanej corocznie ustawie budżetowej, zawierającej budżet, który przedstawiony został w formie podstawowych danych o sytuacji makroekonomicznej państwa (ogólne określenie dochodów i wydatków, deficytu budżetowego, poziomu inflacji), a pozostałe stanowią ramy prawne wykonywania budżetu w danym roku ${ }^{9}$. W tym miejscu podnieść należy, że ustawa budżetowa nie może stanowić podstawy prawnej do pobierania dochodów, gdyż zawarte zostały one w ustawach szczegółowych.

Drugi z wymienionych terminów - środki publiczne - należy do jednych z podstawowych pojęć występujących na gruncie ustawy o finansach publicznych. Wymienione zostały one w art. 5 ust. 1 u.f.p. poprzez ich wyliczenie, nawiązując do pięciu kategorii. Analizując cechy charakteryzujące każde z nich, wskazać należy na trzy podstawowe kategorie, które gromadzone i wydatkowane są w sposób określony przez ustawę o finansach publicznych. Do środków publicznych należy zaliczyćc ${ }^{10}$ :

- $\quad$ dochody publiczne, które mają one charakter podstawowy, są bezzwrotne i stanowią zasilenie różnych funduszy publicznych, w tym budżetu państwa,

- $\quad$ przychody publiczne, mające charakter uzupełniający i najczęściej posiadające charakter zwrotny, a także

- $\quad$ środki (dochody) pochodzące z budżetu UE i inne bezzwrotne środki ze źródeł zagranicznych.

W literaturze z zakresu prawa finansowego zwraca się dużą uwagę na charakter katalogu środków publicznych. Zdaniem E. Ruśkowskiego posiada on różnorodny charakter. Przede wszystkim katalog środków publicznych, który zawarty został w art. 5 u.f.p., nie zawiera klasycznej de-

9 M. Haczkowska (red.), Konstytucja Rzeczypospolitej Polskiej. Komentarz, Lexis Nexis 2014.

10 B. Kucia-Guściora, Środki publiczne, nadwyżka i deficyt sektora finansów publicznych, [w:] P. Smoleń (red.), Ustawa o finansach publicznych. Komentarz, Warszawa 2012, s. 95. 
finicji, mając charakter zamknięty ${ }^{11}$. Odmienny pogląd $w$ omawianej kwestii prezentuje Z. Ofiarski. Zwraca on uwagę, że ustawodawca użył sformułowania „, innych źródeł”"2. Użycie tego zwrotu oznacza, że zdaniem ustawodawcy jest to katalog otwarty i należy zaliczyć do niego środki publiczne, które nie zostały wymienione z nazwy w ustawie o finansach publicznych. Bez wątpienia do takich środków publicznych należy zaliczyć cła.

W konkluzji należy podzielić pogląd J.M. Salachny, zgodnie z którym środkami publicznymi są finansowe środki pieniężne, które zostały otrzymane z określonych tytułów i źródeł przez podmioty - jednostki sektora finansów publicznych lub uiszczone na rzecz budżetu publicznego ${ }^{13}$. W momencie ich pozyskania przez instytucję (lub organ władzy) wykonującą zadania publiczne stają się jej własnością, zwiększając tym samym majątek publiczny, który gromadzony jest w celu pokrycia wydatków publicznych oraz rozchodów publicznych.

\section{Dochody budżetowe uzyskiwane z ceł - analiza normatywna}

Analizując dochody budżetowe uiszczane $\mathrm{z}$ ceł $\mathrm{w}$ polskim porządku prawnym, należy wskazać na ich charakter prawny. Dochody budżetowe zostały jednoznacznie określone w art. 52 ust. 2 pkt 1 ustawy o finansach publicznych jako dochody stanowiące prognozy ich wielkości, których kwoty ustala się na poziomie minimalnym, jaki powinien zostać osiągnięty dla realizacji planowanych wydatków publicznych. Prognozy budżetowe opierają się o doświadczenia, które zebrane zostały w poprzednich okresach planowania, a w szczególności dotyczących wydajności finan-

11 E. Ruśkowski, Środki publiczne, nadwyżka i deficyt sektora finansów publicznych, [w:] E. Ruśkowski, J.M. Salachna (red.), Nowa ustawa o finansach publicznych wraz z ustawq wprowadzajqca, Gdańsk 2010, s. 42.

12 Z. Ofiarski, Przepisy ogólne, [w:] M. Karlikowska, W. Miemiec, Z. Ofiarski, K. Sawicka (red.), Ustawa o finansach publicznych. Komentarz, Wrocław 2010, s. 24.

13 J.M. Salachna, Konstrukcja legalnej definicji środków publicznych i jej konsekwencje, [w:] E. Ruśkowski (red.), System prawa finansowego, t. II, Prawo finansowe sektora finansów publicznych, Warszawa 2010, s. 85. 
sowej określonego źródła $\mathrm{w}$ danych warunkach ${ }^{14}$. Sposób gromadzenia środków publicznych z poszczególnych tytułów określają odrębne usta$\mathrm{wy}^{15}$, co skutkuje dużym rozproszeniem przepisów w różnych aktach prawnych. I tak np. przez użycie przez ustawodawcę w treści art. 2 pkt. 4 u.f.p. terminu „odrębne ustawy” należy rozumieć nie tylko ustawy prawa materialnego odnoszące się do danin publicznych, ale także ustawy określające procedurę, tryb gromadzenia środków publicznych, sposób ustalania zobowiązań, zasady wymiaru, wysokości, poboru oraz egzekucji środków publicznych. Ze względu na różne formy „środków publicznych” np. daniny publiczne (podatki, opłaty, cła), wpływy o charakterze cywilnoprawnym (spadki, zapisy, darowizny), wpływy o charakterze kapitałowym (dywidendy, emisja papierów wartościowych) - nie jest możliwe stworzenie całościowej regulacji w jednym kompletnym akcie prawnym. Powoduje to konieczność stosowania odrębnych regulacji prawnych do każdego rodzaju dochodu publicznego i akceptowania dużego ich rozproszenia. W przypadku gromadzenia środków publicznych w postaci danin publicznych należy wskazać na przepisy nie tylko ustawy Ordynacja podatkowa $^{16}$, a także przepisy ustaw podatkowych oraz innych ustaw, na podstawie których pobierane są należności, stanowiące dochód budżetu państwa, a do których zastosowanie mają przepisy Ordynacji podatkowej (np. opłata publiczna).

W przypadku dochodów budżetowych uzyskiwanych z ceł należy zauważyć, iż zgodnie z treścią art. 90 ust. 3 Konstytucji RP regulacje prawa celnego są stanowione przez organizację międzynarodową. Ponadto istotne jest, że unormowania unijnego prawa celnego opierają się na rozporządzeniach Parlamentu Europejskiego i Rady Europejskiej. Zgodnie z art. 288 TFUE rozporządzenia unijne mają zasięg ogólny, wiążą w całości i są bezpośrednio stosowane we wszystkich państwach członkowskich. Należą one do aktów prawnych o charakterze ponadnarodowym i podle-

14 E. Ruśkowski, Zasady gospodarowania finansami publicznymi, [w:] E. Ruśkowski, J.M. Salachna (red.), Nowa ustawa..., s. 189.

15 Art. 42 ust. 1 u.f.p.

16 Ustawa z dnia 29 sierpnia 1997 r. Ordynacja podatkowa (tekst jedn. Dz.U. z 2017 r., poz. 201 ze zm.). 
gają stosowaniu w porządkach prawnych państw członkowskich bez konieczności podejmowania dodatkowych działań implementacyjnych. Powoduje to, że rozporządzenia wydane przez instytucje unijne zastępują, jeśli idzie o hierarchię aktów normatywnych, krajową ustawę, posiadając pierwszeństwo w ich stosowaniu ${ }^{17}$.

Jak już zauważono wcześniej, z pojęciem dochodów budżetowych nierozerwalnie związane są środki publiczne. Elementem składającym się na treść pojęcia środków publicznych są dochody publiczne ${ }^{18}$, w skład których wchodzą daniny publiczne ${ }^{19}$ oraz pozostałe dochody publiczne ${ }^{20}$. Oznacza to, że katalog dochodów budżetu państwa jest bardzo szeroki i wskazany został nie tylko w art. 5 ust. 2 u.f.p., ale również w art. 60 i 111 u.f.p., które są jego uzupełnieniem. Katalog ten jest katalogiem otwartym, ponieważ zawiera odesłanie do innych ustaw i umów międzynarodowych, w których mogą zostać określone dochody publiczne. Analizując przedmiotowe zagadnienie, należy zwrócić uwagę na funkcje dochodów publicznych. Utożsamiane są one przede wszystkim z celami, dla których ustanawia się poszczególne tytuły dochodów publicznych lub ze skutkami, które wynikają z ich pobierania. Celem wprowadzenia danego rodzaju dochodu publicznego jest realizacja funkcji fiskalnej bądź funkcji interwencyjnej (stymulacyjnej), która polega na zachęceniu lub zniechęceniu podmiotu obciążonego świadczeniem publicznym do określonego zachowania. Podstawową zasadą wynikającą z finansów publicznych, jest to, iż dochody publiczne pobierane są w celu sfinansowania potrzeb publicznych. W literaturze przedmiotu funkcje fiskalne dochodów publicznych nie są negowane. Inaczej jest $\mathrm{z}$ funkcjami interwencyjnymi dochodów publicznych, zwłaszcza gdy poszczególne tytuły obciążeń nie tylko nie mogą, lecz wręcz nie powinny zapewnić napływu dochodów publicznych. Jak słusznie wskazuje C. Kosikowski, cele dochodów publicznych są liczne i nie posiadają jednolitego charakteru ${ }^{21}$, czego przykładem mogą

17 A. Drozdek, Charakter prawny cła jako daniny publicznej w krajowym i unijnym prawie celnym, Szczecin 2017, s. 57.

Art. 5 ust. 2 u.f.p.

Art. 5 ust. 2 pkt 1 u.f.p.

Art. 5 ust. 2 pkt 2-8 u.f.p.

C. Kosikowski, Ustawa o finansach publicznych. Komentarz, Warszawa 2011, s. 40-41. 
być cła, które są stosowane nie tylko w celach fiskalnych, ale także znajdują zastosowanie w celach ochronnych oraz prohibicyjnych.

Podejmując dalszą część rozważań, trzeba zwrócić uwagę, że wśród dochodów publicznych stanowiących daniny publiczne, o których stanowi art. 5 ust. 2 pkt 1 ustawy o finansach publicznych, nie wymieniono wprost ceł. Mimo to należą one bez wątpienia do kategorii danin publicznych, a obowiązek ich ponoszenia na rzecz związku publicznoprawnego (państwa, Unii Europejskiej) wynika z odrębnych ustaw i umów międzynarodowych $^{22}$. Podkreślenia wymaga fakt, iż cło jest specyficznym rodzajem daniny publicznej, która pobierana jest od podmiotów dokonujących wymiany międzynarodowej. W takim rozumieniu mieści się ono w katalogu danin publicznych wymienionych w powyższym przepisie. Rozważając treść powołanej regulacji prawnej, należy zwrócić uwagę, że katalog danin publicznych tworzą świadczenia pieniężne, które stanowią dochód państwa, jednostek samorządu terytorialnego, państwowych funduszy celowych bądź pozostałych jednostek sektora finansów publicznych. Obecnie cła pobierane przez polską administrację celną z tytułu importu towarów stanowią przede wszystkim dochód budżetu UE. Powoduje to, że należą one do ważnego elementu systemu finansowego prawa unijnego, ponieważ już z chwilą przystąpienia Polski do Unii Europejskiej aż 75\% zaksięgowanych kwot wynikających z ceł odprowadzana była do budżetu ogólnego Unii Europejskiej. Z kolei od 1 października 2016 r. kwota zaksięgowanego cła, którą należy odprowadzić do budżetu Unii, wzrosła do $80 \%{ }^{23}$. Oznacza to, że z racji funkcjonowania unii celnej pobierane przez polskie organy celne cło jest przede wszystkim dochodem budżetu Unii Europejskiej, a Polska tylko poprzez swój budżet przekazuje należności z tego tytułu do budżetu UE, zatrzymując - na poczet kosztów poboru 20\% kwoty cła. Pogląd ten potwierdza regulacja prawna zawarta w art. 125 ust. 1 pkt 2 u.f.p., która wskazuje, że do środków własnych Unii Eu-

22 Por. decyzja Rady nr 2014/335/UE, Euratom z dnia 26 maja 2014 r. w sprawie systemu zasobów własnych Unii Europejskiej (Dz.Urz. UE. L 168 z 7 czerwca 2014 r., s. 105) - dalej powołana jako decyzja Rady nr 2014/335/UE; Traktat o funkcjonowaniu Unii Europejskiej (wersja skonsolidowana w brzmieniu nadanym traktatem lizbońskim, Dz.Urz. UE C 83 z 30 marca 2010 r., s. 47).

23 Zob. art. 2 ust. 1 lit. a) oraz ust. 3 decyzji Rady nr 2014/335/UE. 
ropejskiej zalicza udział we wpływach pochodzących z ceł, opłat rolnych i cukrowych. W Polsce cła stanowią jedno ze źródeł dochodów budżetu państwa oraz wymieniane są jako drugi, obok podatków, podstawowy typ danin publicznych, które zapewniają wpływy do budżetu państwa ${ }^{24}$. W chwili obecnej cła jako środek ochronny występuje w budżecie państwa po stronie zarówno dochodów, jak i wydatków (przed akcesją Polski do Unii Europejskiej cła występowały tylko po stronie wpływów). Jako dochód budżetowy wpływy z ceł odprowadzane są przez naczelnika urzędu celno-skarbowego na rachunek budżetu państwa. Po stronie wydatków cła są jednym z elementów dochodów Unii Europejskiej, stanowiąc tradycyjne środki własne.

Analizując miejsce cła w systemie dochodów budżetu państwa, należy podzielić pogląd prezentowany w literaturze przedmiotu, iż cło jest odrębnym rodzajem źródeł dochodów budżetowych, wchodzący w skład systemów niepodatkowych ${ }^{25}$. Argumentem przemawiającym za tym jest fakt, że dochodami niepodatkowymi należy nazwać wszystkie dochody budżetowe, które nie są podatkami. W ustawie o finansach publicznych cła zostały wyodrębnione jako odrębne dochody budżetowe, które nie są ani podatkiem, ani opłatą ${ }^{26}$, natomiast stanowi odrębne źródło dochodów budżetowych. Obowiązek nałożenia oraz uiszczenia ceł wynika z regulacji unijnego prawa celnego, a pobierane są przez uprawnione do tego organy celne. Kluczową rolę wśród źródeł unijnego prawa celnego odgrywa rozporządzenie Parlamentu Europejskiego i Rady (UE) nr 952/2013 z dnia 9 października 2013 r. ustanawiające unijny kodeks celny (wersja przekształcona) $)^{27}$. Podstawowe znaczenia posiada również rozporządzenie Rady nr 2658/87 z dnia 23 lipca 1987 r. w sprawie nomenklatury taryfowej i statystycznej oraz w sprawie Wspólnej Taryfy Celnej ${ }^{28}$, w której

\footnotetext{
Art. 111 pkt 2 u.f.p.

K. Sawicka, Prawo celne w zarysie, Wrocław 2003, s. 60; Z. Ofiarski, Ogólne prawo podatkowe. Zagadnienia materialno-prawne i proceduralne, Warszawa 2010, s. 1920; A. Drozdek, Cło jako niepodatkowa należność budżetowa, część II, „Monitor Prawa Celnego i Podatkowego” 2012, nr 1, s. 18.

Por. art. 111 ust. 2 u.f.p.

Dz.Urz. UE L Nr 269 z 10 października 2013 r., s. 1 ze zm. (dalej: UKC).

Dz.Urz. WE L 256 z 7 września 1987 r., s. 1.
} 
zawarta została taryfa celna Unii. Z kolei zawarte w taryfie celne stawki celne mają zasadnicze znaczenie dla obliczenia wysokości cła ${ }^{29}$. Unijne przepisy prawa celnego w zakresie transakcji międzynarodowego obrotu towarowego zostały uzupełnione przez krajowe regulacje państw członkowskich, które zostały upoważnione tylko w niektórych przypadkach do stanowienia przepisów krajowych normujących problematykę celną ${ }^{30}$. Z punktu widzenia prowadzonych rozważań istotne jest, że stawki celne mogą zostać wielokrotnie zmienione w trakcie roku kalendarzowego ${ }^{31}$. Dzięki zastosowaniu takiego rozwiązania, w przypadku inflacji lub deflacji cło samoczynnie wpływa na wahania cen, co pozwala uniknąć konieczności dostosowywania taryfy celnej do zmieniających się cen towarów. Poza tym w przypadku dużej inflacji, która jest zjawiskiem bardziej powszechnym niż deflacja, cła stanowią stabilne źródło dochodów budżetowych.

Prowadząc przedmiotowe rozważania, niezbędne jest wskazanie, że cło realizuje przede wszystkim funkcję fiskalną. Wyraża się ona w dostarczaniu dochodów związkowi publicznoprawnemu. Funkcja fiskalna, którą pełnią one $\mathrm{w}$ obrocie towarowym $\mathrm{z}$ zagranicą, podkreślona została w arendze do decyzji Rady nr 2014/335/UE, Euratom z dnia 26 maja 2014 r. w sprawie systemu zasobów własnych Unii Europejskiej ${ }^{32}$. Zgodnie z jej brzmieniem system zasobów własnych Unii zapewnia odpowiednie zasoby na kształtowanie poszczególnych polityk Unii w sposób uporządkowany, przy uwzględnieniu potrzeby ścisłej dyscypliny budżetowej. Ponadto mając na uwadze poczynione na wstępie rozważania, należy zauważyć, że z dniem 1 maja 2004 r. Polska, przystępując do Unii Europejskiej, została objęta wspólnym obszarem celnym Unii ${ }^{33}$. Konsekwencją tego było przy-

29 Wspólna Taryfa Celna UE przewiduje stawki konwencyjne, autonomiczne, preferencyjne, obniżone, ryczałtowe, które stosuje się w zależności od pochodzenia towaru (wyrok NSA z dnia 18 lutego 2009 r., sygn. I GSK 297/08, Lex nr 516679). Por. art. 1 ustawy z dnia 19 marca 2004 r. Prawo celne (tekst jedn. Dz.U. z 2016 r., poz. 1880 ze zm.).

31 Wyrok WSA w Gorzowie Wlkp. z dnia 14 czerwca 2006 r., sygn. I SA/Go 2084/05, Lex nr 853858 oraz wyrok TK z dnia 25 kwietnia 2001 r., sygn. K 13/01, OTK 2001/4/81, Lex nr 48034.

32 Dz.Urz. UE L 168 z 7 czerwca 2014 r., s. 105.

33 Art. 28 TFUE. 
jęcie przez Polskę Wspólnej Taryfy Celnej Unii Europejskiej oraz zniesienia ceł przywozowych i wywozowych pomiędzy państwami członkowskimi $^{34}$ i zniesienie formalności celnych $\mathrm{w}$ obrocie towarowym między Polską a krajami członkowskimi UE. W konsekwencji spowodowało to, że nastąpiła ogólna degresja ceł, gdyż cła pobierane są tylko od towarów sprowadzanych spoza krajów członkowskich Unii, a obrót towarowy, który odbywa się między krajami UE w ramach jednolitego rynku wewnętrznego, jest bezcłowy. Ponadto krajowy przedsiębiorca uzyskał możliwość dokonywania odpraw celnych towarów importowanych z państw trzecich w dowolnym urzędzie celnym znajdującym się na obszarze UE.

W tym miejscu podkreślić należy, że wysokość naliczonego i pobranego cła przez organy celne na podstawie unijnego prawa celnego stanowi również podstawę naliczenia środków parataryfowych, którymi są podatek od towarów i usług oraz podatek akcyzowy w imporcie towarów. Powoduje to, że cło jako źródło dochodów w polskim porządku prawnym jest czułym instrumentem, którym może posługiwać się Komisja Europejska. Z jednej strony, pojawia się możliwość wykorzystywania ceł jako istotnego źródła dochodów publicznych, przy czym nadużywanie ceł może obrócić się przeciwko Unii Europejskiej. Z drugiej strony wprowadzenie wysokich stawek celnych na cła przywozowe może zniechęcać podmioty do działalności importowej, co pociągnie za sobą niższe dochody publiczne z tytułu ceł.

Uwzględniając powyższe rozważania, należy uznać, iż po przystąpieniu Polski do Unii Europejskiej cła stanowią w sensie podmiotowym i przedmiotowym źródło dochodów budżetu unijnego, w przeciwieństwie do pozostałych danin publicznych, które zasilają dochody budżetu państwa lub jednostek samorządu terytorialnego. Instytucja cła stanowi osobną kategorię dochodów publicznych, która cechuje się przymusowością. Pobierane jest przez organy administracji celnej na podstawie szczegółowej Wspólnej Taryfy Celnej UE od podmiotów dokonujących obrotu towarowego z zagranicą, w związku z przemieszczaniem się towaru przez granicę celną państwa lub grupy państw tworzących unię celną, co pod-

34 Art. 30 TFUE. 
kreśla szczególny charakter tego świadczenia jako dochodu budżetowego w polskim porządku prawnym. Ujęcie cła w katalogu danin publicznych wynika z realizacji celów publicznych, jak również z faktu, iż stanowi źródło dochodów publicznych, które jest niezbędne dla funkcjonowania związku publicznoprawnego. System zasobów własnych Unii Europejskiej zapewnia w ten sposób odpowiednie środki finansowe na prowadzenie unijnej polityki w poszczególnych dziedzinach w sposób uporządkowany, uwzględniając potrzeby ścisłej dyscypliny budżetowej. W konsekwencji cło jest świadczeniem, którego obowiązek ponoszenia wynika $\mathrm{z}$ regulacji unijnego prawa celnego, a więc $\mathrm{z}$ odrębnych regulacji unijnych. Cło jako jedyne świadczenie pobierane $\mathrm{w}$ obrocie towarowym z zagranicą stanowi dochód organizacji międzynarodowej, jaką jest Unia Europejska, oraz państw członkowskich.

\section{Konkluzje}

Analiza materiału normatywnego dokonana w niniejszym opracowaniu pozwala na sformułowanie bezdyskusyjnych wniosków. Do najważniejszych należy zaliczyć:

1. Instytucja cła jako jedna $\mathrm{z}$ form danin publicznych nierozerwalnie związana jest $\mathrm{z}$ obrotem towarowym $\mathrm{z}$ zagranicą. $\mathrm{W}$ strukturze dochodów budżetu państwa cła są ujmowane w kategorii dochodów niepodatkowych - jeden z rodzajów dochodów o charakterze niepodatkowym.

2. W wyniku ustanawiania oraz pobierania ceł można realizować nie tylko cele fiskalne, ale także pozafiskalne. Cel fiskalny ceł polega na pobieraniu określonych wpływów na rzecz związku publicznoprawnego, który następnie przeznaczony jest na finansowanie różnych zadań publicznych. Cło jako instrument finansowy realizuje także cele ochronne (pozafiskalne), których zadaniem jest utrudnienie, a nawet uniemożliwienie napływu towarów z zagranicy, co stanowić może cel prowadzonej polityki gospodarczej Unii Europejskiej.

3. Cło jako instytucja prawa finansowego jest nie tylko częścią dochodu budżetu państwa, ale również budżetu Unii Europejskiej. W wyniku 
funkcjonowania unii celnej aż 80\% pobranych przez organy celne państw członkowskich UE ceł przekazywana jest do budżetu ogólnego Unii Europejskiej. Natomiast budżety krajowe, przekazując należności z tego tytułu do budżetu UE, zatrzymują w budżetach krajowych 20\% pobranych ceł jako koszty poboru.

4. Dochody Unii Europejskiej i Polski pochodzące z ceł wynikają z przepisów unijnego prawa celnego, które m.in. regulują elementy konstrukcyjne ceł oraz zasady podlegania obowiązkowi celnemu.

5. Wykorzystując stawki celne, ulgi lub zwolnienia celne, można odpowiednio wpływać na zachowania podmiotów uczestniczących w wymianie międzynarodowej. Poziom dochodów uzyskiwanych z ceł zależy również od wielkości importu, kursu walutowego, skali wykorzystania środków taryfowych (takich jak np. zawieszenie poboru ceł czy kontyngent taryfowy) oraz stosowanych przez Unię Europejską środków pozataryfowych polityki celnej (np. zakazu przywozu, ograniczeń ilościowych). Wykorzystywanie ceł do osiągania celów fiskalnych lub pozafiskalnych uwarunkowane jest mniejszym lub większym zaangażowaniem związku publicznoprawnego i jego struktur organizacyjnych w procesy gospodarcze i społeczne.

\section{Bibliografia:}

Drozdek A., Cło jako niepodatkowa należność budżetowa, część II, „Monitor Prawa Celnego i Podatkowego" 2012, nr 1, s. 17-20.

Drozdek A., Charakter prawny cła jako daniny publicznej w krajowym i unijnym prawie celnym, BW Jan Brodziński, Szczecin 2017.

Haczkowska M. (red.), Konstytucja Rzeczypospolitej Polskiej. Komentarz, Lexis Nexis 2014.

Kosikowski C., Ustawa o finansach publicznych. Komentarz, Lexis Nexis Polska, Warszawa 2011.

Kosikowski C., Problem suwerenności finansowej państwa członkowskiego Unii Europejskiej, [w:] L. Etel, M. Tyniewicki (red.), Finanse publiczne i prawo finansowe - realia i perspektywy zmian. Księga Jubileuszowa dedykowana Profesorowi Eugeniuszowi Ruśkowskiemu, Białystok 2012. 
Kucia-Guściora B., Środki publiczne, nadwyżka i deficyt sektora finansów publicznych, [w:] P. Smoleń (red.), Ustawa o finansach publicznych. Komentarz, C.H. Beck, Warszawa 2012.

Modzelewski W., Pyssa J., Zarys prawa celnego, [w:] Litwińczuk H. (red.), Prawo finansowe. Tom II, Prawo podatkowe, Oficyna Prawa Polskiego, Warszawa 2012.

Ofiarski Z., Ogólne prawo podatkowe. Zagadnienia materialno-prawne i proceduralne, Lexis Nexis, Warszawa 2010.

Ofiarski Z., Przepisy ogólne, [w:] M. Karlikowska, W. Miemiec, Z. Ofiarski, K. Sawicka (red.), Ustawa o finansach publicznych. Komentarz, Presscom, Wrocław 2010.

Ruśkowski E., Środki publiczne, nadwyżka i deficyt sektora finansów publicznych, [w:] Ruśkowski E., Salachna J.M. (red.), Nowa ustawa o finansach publicznych wraz z ustawq wprowadzajqcq, ODDK, Gdańsk 2010.

Ruśkowski E., Zasady gospodarowania finansami publicznymi, [w:] E. Ruśkowski, J.M. Salachna (red.), Nowa ustawa o finansach publicznych wraz z ustawq wprowadzajq̨cq, ODDK, Gdańsk 2010.

Salachna J.M., Konstrukcja legalnej definicji środków publicznych i jej konsekwencje, [w:] System prawa finansowego. T. II, Prawo finansowe sektora finansów publicznych, E. Ruśkowski (red.), Oficyna a Wolters Kluwer Business, Warszawa 2010.

Sawicka K., Prawo celne w zarysie, Kolonia Limited, Wrocław 2003.

Sondel J., Słownik łacińsko-polski dla prawników i historyków, Towarzystwo Autorów i Wydawców Prac Naukowych Universitas, Kraków 2009. 